\title{
Prevalence of and risk factors for methicillin-resistant Staphylococcus aureus nasal carriage in the West of Iran: a population-based cross-sectional study
}

\author{
Elham Ahmadi ${ }^{1 *}$ D , Mohammad Khojasteh ${ }^{1}$, Seyed Mohammad Mortazavi ${ }^{1}$, Fatemeh Khan-Mohammadi ${ }^{2}$, \\ Ali Kazemnia ${ }^{3}$, Javad Beheshtipour ${ }^{4}$ and Mahdieh Raeeszadeh ${ }^{5}$
}

\begin{abstract}
Background: Several reports designate the recent increase in community-acquired methicillin-resistant Staphylococcus aureus (CA-MRSA) nasal carriage. Because of the scanty information regarding the nasal carriage sate of MRSA in the west of Iran, the purpose of the present study was to determine the frequency of CA-MRSA in Sanandaj city.

Methods: Swabs collected from anterior nares of 600 volunteers were analyzed for the presence of S. aureus. The isolates were further investigated for methicillin resistance by using the cefoxitin disk diffusion test, followed by PCRamplification of the mecA gene. SCCmec types and the presence of the Panton-Valentine Leukocidin (pv) encoding genes were determined through PCR. Finally, the antimicrobial susceptibility of the isolates was determined by the agar diffusion method.

Results: Nasal screening identified 181 S. aureus, of which 55 isolates were MRSA. SCCmec types IV and V were detected in MRSA at frequencies of 80 and 20\%, respectively. The overall frequency of pvl genes among the MRSA isolates was $14.54 \%$. MRSA isolates were highly susceptible (98.18\%) to mupirocin, gentamicin, and fusidic acid.

Conclusions: The high prevalence of CA-MRSA carriage in the population could pose a serious public health concern for the region. Additionally, advent of drug-resistant pv-positive strains demands continuous surveillance on the colonization state of CA-MRSA in order to prevent dissemination of the bacterium in the community.
\end{abstract}

Keywords: CA-MRSA, SCCmec, PVI, Antibiogram, Iran

\section{Background}

Staphylococcus aureus is one of the major human infectious agents, causing mild to life-threatening manifestations. Anterior nares is the most consistent ecological niche for S. aureus in humans [1]. Almost $50 \%$ of the healthy individuals harbor the bacterium in a persistent or intermittent status, asymptomatically [2]. It is documented that the endogenous source of $S$. aureus is responsible for almost $80 \%$ of staphylococcal infections in carriers [3]. In addition to pervasive increasing in $S$. aureus reservoirs, the advent of community-acquired

\footnotetext{
* Correspondence: elham.ahmadi.vet@gmail.com

${ }^{1}$ Department of Pathobiology, Faculty of Veterinary Medicine, Sanandaj

Branch, Islamic Azad University, Sanandaj, Iran

Full list of author information is available at the end of the article
}

methicillin-resistant S. aureus (CA-MRSA), which is generally multi or extensively drug-resistant, has complicated the therapeutic trials in recent years $[4,5]$. Acquisition of $m e c \mathrm{~A}$ leads to encoding a low affinity penicillin-binding protein (PBP2a). Insertion of the mobile genetic elements carrying mecA in the bacterial chromosome nominates staphylococcal cassette chromosome mec (SCCmec) elements, among which types IV and V are carried by CAMRSA [6, 7]. Further, distribution of diverse antimicrobial resistant genes within the community via resident strains is the other aspect of hazard imposed by CA-MRSA [8]. It is reported that traditional Hospital-acquired MRSA (HA-MRSA) are replaced by CA-MRSA [9]. Likewise, pvlharboring CA-MRSA clones may involve in necrotizing

(c) The Author(s). 2019 Open Access This article is distributed under the terms of the Creative Commons Attribution 4.0 International License (http://creativecommons.org/licenses/by/4.0/), which permits unrestricted use, distribution, and 
pulmonary and skin infections through the expression of Panton-Valentine Leukocidin (PVL) toxin [10].

Despite the studies carried out on CA-MRSA carriage in various part of the world [11-14], and among healthy children [15, 16], medical and non-medical students [8], and outpatients $[17,18]$ in Iran, the prevalence of CAMRSA in the community setting in the west of Iran is totally unknown. Therefore, this study was conducted to evaluate the nasal colonization state of MRSA on healthy individuals in Sanandaj city, west of Iran. Moreover, SCCmec types, presence of $p v l$, and antibiotic resistance profile of the isolates were further analyzed.

\section{Methods}

\section{Samples and data collection}

The frequency of $S$. aureus nasal carriage (SANC) and MRSA was investigated in a cross-sectional study from February 2017 to July 2018 among 600 randomly chosen inhabitants in Sanandaj city based on the non-probability haphazard sampling type. Any sign of clinical illness, hospitalization, and use of antibiotics during the 12 preceding months were excluded from the survey. The participants included 278 female and 322 male. The study was approved by the Ethics Committee of Sanandaj Medical University. An informed consent signed by all the participants or their legal guardians was obtained prior to enrollment. Details of the sampling population are depicted in Table 1.

\section{S. aureus isolation}

Sterile swabs moisture with sterile normal saline (SNS) was used for streaking both anterior nares of each participant. The swabs embedded in SNS were transferred to the microbiology laboratory within maximum two hours and streaked onto Columbia agar (CA, Merck, Germany) with 6\% defibrinated sheep blood. An individual presumptive colony of $S$. aureus (round and convex with an approximate of $1-4 \mathrm{~mm}$ in diameter) from each plate was subcultured on blood agar (BA, Merck, Germany). Phenotypic characterization of the S. aureus isolates were performed based on Gram staining and the biochemical reactions including catalase, coagulase, and
DNase positive bacteria, in addition to yellow appearance on mannitol salt agar (MSA, Merck, Germany).

\section{DNA extraction and molecular analysis}

Genomic DNA of the $S$. aureus isolates were extracted using gram positive bacterial DNA extraction kit (CinnaGen, Iran). The DNA of the isolates were subjected to a species-specific polymerase chain reaction (PCR) based on the nuc gene partial amplification [19]. Initial determination of MRSA was performed using cefoxitin disk (Patanteb, Iran) diffusion test [20], which was followed by mecA gene amplification [21]. SCCmec types (I-V) of MRSA isolates were discriminated in a multiplex PCR reaction as described by Ghaznavi-Rad et al. [22]. Finally, the presence of $p v l$ gene was analyzed as proposed by Lina et al. [23]. Reference strain of S. aureus ATCC 49775 was applied as $p v l$ positive control. Positive controls for SCCmec PCR were as followed: NCTC10442 (SCCmec I), NCTC N315 (SCCmec II), NCTC 85/2082 (SCCmec III), HDE288 (SCCmec IV), and JCSC3624 (SCCmec V).

\section{Antimicrobial susceptibility testing}

Agar disk diffusion method was exploited to assess the antimicrobial susceptibility pattern of isolated S. aureus strains [20]. The used antibiotic disks (Patanteb, Iran) included rifampin $(5 \mu \mathrm{g})$, tetracyclin $(30 \mu \mathrm{g})$, chloramphenicol $(30 \mu \mathrm{g})$, fusidic acid $(10 \mu \mathrm{g})$, trimethoprimsulphamethoxazole $(1.25 / 23.75 \mu \mathrm{g})$, clindamycin $(2 \mu \mathrm{g})$, gentamicin $(10 \mu \mathrm{g})$, erythromycin $(15 \mu \mathrm{g})$, penicillin $(10$ $\mathrm{U})$, vancomycin $(30 \mu \mathrm{g})$, mupirocin $(200 \mu \mathrm{g})$, and ciprofloxacin $(5 \mu \mathrm{g})$. S. aureus ATCC 25923 was used for quality control point.

\section{Statistical analysis}

Demographic characteristics (gender and age-group variables) and risk factors of the studied population were primarily analyzed by bivariate model. $P$ values $\leq 0.05$ indicated statistically significant correlations at the $95.0 \%$ confidence level. Next, multiple logistic regression model was applied. In order to elevate the value of regression model, every given variable with a $P$ value $\leq 0.05$ was

Table 1 Age group and sex characteristics, and distribution of SANC and MRSA

\begin{tabular}{lllllll}
\hline Age & Female volunteers $(n=278)$ & SANC $(n=68)$ & MRSA $(n=13)$ & Male volunteers $(n=322)$ & SANC $(n=113)$ & MRSA $(n=42)$ \\
\hline $1-10$ & 31 & 12 & 3 & 45 & 22 & 7 \\
$>10-20$ & 27 & 11 & 4 & 39 & 27 & 12 \\
$>20-30$ & 34 & 7 & 1 & 42 & 13 & 3 \\
$>30-40$ & 67 & 3 & 1 & 52 & 9 & 3 \\
$>40-50$ & 58 & 6 & 2 & 54 & 12 & 6 \\
$>50-60$ & 33 & 14 & 1 & 46 & 12 & 9 \\
$>60-70$ & 28 & 15 & 1 & 44 & 2 \\
\hline
\end{tabular}


entered in the final multiple logistic model. The goodness of fit regarding multiple logistic regression model was evaluated by Hosmer and Lemeshow test. The results were expressed as $P$ value and adjusted odds ratio (Adjusted OR) with a 95\% confidence interval (CI 95\%). Median ages expressed as mean \pm SEM.

\section{Results}

In the present research, 181 (30.16\%) colonized S. aureus isolates were detected, among which 68 (11.33\%) and $113(18.83 \%)$ strains were isolated from female and male subjects, respectively. The overall prevalence of MRSA in this study was 55 out of $181 \mathrm{~S}$. aureus isolates, identified phenotypically and then confirmed in a mecA-based PCR assay. The most affected age-group among females and males were $>60-70$ and $>10-20$ years-old groups, respectively. Thirteen $(2.16 \%)$ and 42 (7\%) female and male candidates were detected as MRSA nasal carriers, respectively (Table 1).

The individuals with highest carriage rate of MRSA in both genders were in $>10-20$ age group. The prevalence of MRSA in men was rather higher than that of women (Table 2). The median age of women and men enrollers were $36.27 \pm 1.06$ and $36.08 \pm 1.09$ years, respectively. The risk of MRSA (Adjusted OR: 3.86; 95\% CI: 1.70-8.76) infection was significant with gender (Table 3). Meanwhile, significance association was observed between MRSA frequency with age (Adjusted OR: 0.92; 95\% CI: 0.78-1.10) (Table 3). Besides, in bivariate logistic regression analysis, a significant association was revealed between the frequency of MRSA with some independent risk factors including skin and soft tissue infection in the last 12 months (Crude OR $=46.57,95 \% \mathrm{CI}: 2.03-1068.89$ ), occupation (Crude OR $=1.32$, 95\% CI: 1.24-3.52), and the presence of household members who have a profession in hospital care (Crude OR $=13.07,95 \%$ CI: 2.44-70.11) (Table 2). All of the above mentioned risk factors remained associated in the multiple logistic regression analysis, including skin and soft tissue infection in the last 12 months (Adjusted $\mathrm{OR}=4.70,95 \% \mathrm{CI}: 1.22-18.18$ ), occupation (Adjusted OR $=0.22$, 95\% CI: 0.09-0.51), and the presence of household members who have a profession in hospital care (Adjusted OR = 5.24, 95\% CI: 1.86-14.76) (Table 3). No statistical relationship was identified between the other risk factors depicted in Table 2 and MRSA state. The $P$ value, crude odds ratio and confidence interval $(\mathrm{CI})$ of the risk factors are accessible in Table 2.

A total of 44 (80\%) MRSA isolates carried SCCmec type IV, among which eight isolates harbored $p v l$ gene. The frequency of $p v l$ and SCCmec type IV subtypes are represented in Table 4. In addition, SCCmec type V was detected in $11(20 \%)$ MRSA isolates and only one of them harbored $p v l$ gene. Other types of SCCmec including types I, II, and III were not detected in any isolates.
The antibiotic resistance pattern of $S$. aureus including MRSA is presented in Table 5. Drug-resistance (resistance to at least 2 classes of antibiotics) was observed in $132(72.92 \%)$ and $47(87.27 \%)$ total S. aureus and MRSA isolates, respectively. Resistance to penicillin allocated the highest rate of resistance, following by clindamycin, erythromycin, and ciprofloxacin among the total and MRSA isolates. All MRSA isolates were susceptible to fusidic acid, gentamicin, and mupirocin, except one isolate. Besides, high rates of susceptibility were observed against the three above antibiotics in total isolated $S$. aureus.

\section{Discussion}

Emergence and distribution of CA-MRSA clones is a universal public health issue. High frequency of colonized $S$. aureus detected in the present survey is a matter of concern as nasal carriers are at risk of acquiring endogenous Staphylococcal infections [8]. Relatively poor personal hygiene such as facial, hand, and nostril cleaning habit is a probable reason of the high rate of SANC in the region [24]. Although a reverse association has been stated between SANC and age [14], higher prevalence of SANC among elderly women in this study is ambiguous. This may be related to hormonal disposition [13]. As an evidence, consumption of hormonal contraceptives is identified as a risk factor for SANC [25]. On one hand, female sex hormones direct an immunomodulating effect which may modify the host innate and adaptive responses against infections. This is particularly about estrogen through the exertion of anti-inflammatory and pro-inflammatory effects at different physiological levels $[26,27]$. On the other hand, the dynamics of SANC is indirectly affected by the existence of sex steroid receptors in the anterior nares, in addition to the microenvironment of nasal cavity which is influenced by sex hormones $[24,28]$. The peak competition of respiratory pathogens to colonize in the anterior nares is in the first years of life, by which interfering of the bacteria confers their elimination or establishment [1]. Higher prevalence of SANC state is consistently documented in male gender $[8,13,14]$. Despite this, some observations have documented no differences regarding the SANC state in both genders [29]. Empirically experience of the authors denotes the less habit of hand washing among young boys. Although the impact of gender on SANC frequency is not completely known so far, enhanced attitude of female sex toward health issues, particularly personal hygiene, may influence the bacterial colonization rate [8].

The reported incidences of SANC in different studies vary, depending on the sampling sites and methods, and the methodology applied [12]. Lower frequency of SANC among apparently healthy individuals have been reported from Spain (19.1\%) [12], Norway (27\%) [30], 
Table 2 Bivariate analysis of demographic information and risk factors for MRSA

\begin{tabular}{|c|c|c|c|c|c|c|}
\hline \multirow[t]{2}{*}{ Factor } & \multirow{2}{*}{$\begin{array}{l}\text { SANC Frequency } \\
\text { (\% column) }\end{array}$} & \multicolumn{2}{|l|}{ MRSA } & \multirow[t]{2}{*}{$p$} & \multirow[t]{2}{*}{ Crude OR } & \multirow[t]{2}{*}{$95 \% \mathrm{Cl}$} \\
\hline & & Positive No. (\%) & Negative No. (\%) & & & \\
\hline \multicolumn{7}{|l|}{ Sex } \\
\hline Male & 113 (35.09) & $42(37.17)$ & $71(62.83)$ & 0.001 & 6.48 & $2.13-19.66$ \\
\hline Female & $68(24.46)$ & 13 (19.12) & 55 (80.88) & & & \\
\hline \multicolumn{7}{|l|}{$\mathrm{Age}^{\mathrm{a}}$} \\
\hline $1-10$ years & $34(44.74)$ & $10(29.41)$ & $24(70.59)$ & - & 1 & - \\
\hline 10-20 years & $38(57.58)$ & $16(42.10)$ & $22(57.90)$ & 0.002 & 10.64 & $2.37-47.79$ \\
\hline 20-30 years & $20(26.32)$ & $4(20.00)$ & $16(80.00)$ & 0.78 & 1.33 & $0.17-10.52$ \\
\hline 30-40 years & $12(10.08)$ & $4(33.33)$ & $8(66.77)$ & 0.48 & 2.18 & $0.25-19.29$ \\
\hline 40-50 years & $18(16.07)$ & $8(44.44)$ & $10(55.56)$ & 0.05 & 8.85 & $1.02-76.89$ \\
\hline $50-60$ years & $32(40.51)$ & $10(31.25)$ & $22(68.75)$ & 0.08 & 4.62 & $0.83-25.53$ \\
\hline $60-70$ years & 27 (37.50) & $3(11.11)$ & 24 (88.99) & 0.19 & 0.12 & $0.004-3.03$ \\
\hline \multicolumn{7}{|c|}{ Hospital visit in the last 3 months } \\
\hline Yes & $58(32.77)$ & $20(34.48)$ & $38(65.51)$ & 0.09 & 2.96 & $0.85-10.36$ \\
\hline No & $123(29.08)$ & $35(28.45)$ & $88(71.54)$ & & & \\
\hline \multicolumn{7}{|c|}{ Chronic renal disorder } \\
\hline Yes & $27(39.71)$ & $11(40.74)$ & $16(59.25)$ & 0.91 & 1.14 & $0.14-9.01$ \\
\hline No & $154(28.95)$ & $44(28.57)$ & $110(71.42)$ & & & \\
\hline \multicolumn{7}{|l|}{ Smoking habits $^{a}$} \\
\hline Ex-smoker & $22(44.90)$ & $4(18.18)$ & $18(81.81)$ & - & 1 & - \\
\hline Current smoker & $39(31.97)$ & $16(41.02)$ & $23(58.97)$ & 0.09 & 12.96 & $0.64-263.94$ \\
\hline Non-smoker & $120(27.97)$ & $35(29.16)$ & $85(70.83)$ & 0.23 & 6.4 & $0.3-136.99$ \\
\hline \multicolumn{7}{|l|}{ Occupation } \\
\hline Yes & $97(35.93)$ & $22(22.68)$ & $75(77.31)$ & 0.04 & 1.32 & $1.24-3.52$ \\
\hline No & $84(25.45)$ & $33(39.28)$ & $51(60.71)$ & & & \\
\hline \multicolumn{7}{|c|}{ Household members who have a profession in hospital care } \\
\hline Yes & $36(47.37)$ & $16(44.44)$ & $20(55.55)$ & 0.003 & 13.07 & $2.44-70.11$ \\
\hline No & $145(80.11)$ & $39(26.89)$ & $106(73.10)$ & & & \\
\hline \multicolumn{7}{|c|}{ Skin and soft tissue infection in the last 12 months } \\
\hline Yes & $14(36.84)$ & $9(64.28)$ & $5(35.71)$ & 0.02 & 46.57 & $2.03-1068.89$ \\
\hline No & $167(29.72)$ & $46(27.54)$ & $121(72.45)$ & & & \\
\hline \multicolumn{7}{|l|}{ Allergy } \\
\hline Yes & $15(22.39)$ & $3(20.00)$ & $12(80.00)$ & 0.06 & 0.1 & $0.01-0.82$ \\
\hline No & $166(31.14)$ & $52(11.32)$ & $114(88.68)$ & & & \\
\hline \multicolumn{7}{|l|}{ Diabetes mellitus } \\
\hline Yes & 7 (36.84) & $1(14.28)$ & $6(85.71)$ & 0.9 & 0.04 & $0.001-1.62$ \\
\hline No & $174(29.95)$ & $54(31.03)$ & $20(68.96)$ & & & \\
\hline \multicolumn{7}{|c|}{ Surgery in the last 12 months } \\
\hline Yes & $4(26.67)$ & $1(25.00)$ & $3(75.00)$ & 0.82 & 0.65 & $0.02-25.57$ \\
\hline No & $177(30.26)$ & $54(30.50)$ & $123(69.49)$ & & & \\
\hline \multicolumn{7}{|c|}{ Chronic liver disorder } \\
\hline Yes & $0(0.00)$ & $0(0.00)$ & $0(0.00)$ & 1 & - & - \\
\hline No & $181(30.37)$ & $55(30.38)$ & $126(69.61)$ & & & \\
\hline
\end{tabular}


Table 2 Bivariate analysis of demographic information and risk factors for MRSA (Continued)

\begin{tabular}{|c|c|c|c|c|c|c|}
\hline \multirow[t]{2}{*}{ Factor } & \multirow{2}{*}{$\begin{array}{l}\text { SANC Frequency } \\
\text { (\% column) }\end{array}$} & \multicolumn{2}{|l|}{ MRSA } & \multirow[t]{2}{*}{$p$} & \multirow[t]{2}{*}{ Crude OR } & \multirow[t]{2}{*}{$95 \% \mathrm{Cl}$} \\
\hline & & Positive No. (\%) & Negative No. (\%) & & & \\
\hline \multicolumn{7}{|c|}{ Use of steroids } \\
\hline Yes & $3(25.0)$ & $1(33.33)$ & $2(66.66)$ & 0.22 & 13.95 & $0.21-912.44$ \\
\hline No & $178(30.27)$ & $54(30.38)$ & $124(69.66)$ & & & \\
\hline \multicolumn{7}{|c|}{ Oral contraceptive } \\
\hline Yes & $8(21.62)$ & $3(37.5)$ & $5(62.5)$ & 0.31 & 4.61 & $0.24-89.79$ \\
\hline No & $173(30.73)$ & $52(30.05)$ & $121(69.94)$ & & & \\
\hline \multicolumn{7}{|c|}{ Alcoholism } \\
\hline Yes & $7(41.18)$ & $3(42.85)$ & $4(57.14)$ & 0.388 & 4.04 & $0.176-92.58$ \\
\hline No & $174(29.58)$ & $52(29.88)$ & $122(70.11)$ & & & \\
\hline
\end{tabular}

${ }^{a}$ Regression was used with the first value within variable acting as reference value Variables entered: sex (male versus female), and the other variables, yes versus no. OR: Odds ratio

$\mathrm{Cl}$ : Confidence interval

Kashmir-India (27.92\%) [31], and Germany (21.9\%) [13], while the higher prevalence of SANC (40.4\%) has been documented in Ukraine [32]. It is not out of mind that the prevalence rate of $S$. aureus in this study in underestimated as other sites of body residing S. aureus (skin, vagina, pharynges) did not examined. In addition, enrichment processes did not employed for rising S. aureus isolation.

High level of CA-MRSA in this study poses a risk for not only carriers but also patients and susceptible individuals. The previous history of skin and soft tissue infections is independently associated with MRSA rate. Current studies have also confirmed MRSA colonization with surgical site infections or chronic furunculosis [33, 34]. Despite this, because of some controversial conflicts regarding association of MRSA colonization with several non-infectious skin diseases [35-37], the burden of CAMRSA state in skin and soft tissue infections in the studied district is needed to investigate in details in upcoming studies. Despite the success in preventing recurrent skin infections following nasal decolonization with mupirocin [33], it has been failed in the cases of non-infectious skin

Table 3 Multiple logistic regression analysis of demographic information and risk factors associated with MRSA

\begin{tabular}{|c|c|c|c|}
\hline Risk factors & $p$ & Adjusted OR & $95 \% \mathrm{Cl}$ \\
\hline Sex & 0.001 & 3.86 & $1.70-8.76$ \\
\hline Age & 0.038 & 0.92 & $0.78-1.10$ \\
\hline $\begin{array}{l}\text { Skin and soft tissue infection } \\
\text { in the last } 12 \text { months }\end{array}$ & 0.03 & 4.70 & $1.22-18.18$ \\
\hline Occupation & 0.001 & 0.22 & $0.09-0.51$ \\
\hline $\begin{array}{l}\text { Household members who have } \\
\text { a profession in hospital care }\end{array}$ & 0.002 & 5.24 & $1.86-14.76$ \\
\hline
\end{tabular}

diseases [38]. In other studies undertaken in Iran, the carriage state of MRSA among special groups including healthcare workers [39], children [16], students [8], and hospitalized individuals [40] were 5.3, 1.3, 13.14, and $36.8 \%$, respectively. The nasal colonization rate of MRSA was reported $4.5 \%$ in a community based study carried out in Arak, central Iran [41]. The carriage rate of MRSA in Spain (0.4\%) [12], Bolivia (0.5\%) and Peru (0\%) [11], Brazil (0.9\%) [14], Germany (1.29\%) [13], India (1.83\%) [31], and Ukraine (3.7\%) [32] were lower than the 9.16\% detected in our study. Higher incidence of MRSA nasal carriage $(16.6 \%)$ has been reported by Goud et al. [42], while Scerri et al. [43] and Onanuga et al. [44] has stated approximately close rate of MRSA nasal colonization from Malta (8.8\%) and Niger delta (9\%). Regular close contact with an active case or carrier, traffic to healthcare centers, poor sanitation or economic circumstances, preceding antibiotic prescription, and overcrowding are the plausible reasons to explain the differences of CA-MRSA prevalence in various regions $[45,46]$. There is concordance between the results of the present work and Schaumburg et al. regarding peek colonization rate of the bacterium

Table 4 Frequency of SCCmec type IV subtypes among MRSA isolates

\begin{tabular}{llll}
\hline Subtype & Female & Male & Total \\
\hline IVa & $3(5.45 \%)$ & $15(27.27 \%)$ & $18(32.72 \%)^{*}$ \\
IVb & $0(0 \%)$ & $4(7.27 \%)$ & $4(4.27 \%)^{*}$ \\
IVc & $2(3.63 \%)$ & $11(20 \%)$ & $13(23.63 \%)^{*}$ \\
IVd & $1(1.81 \%)$ & $0(0 \%)$ & $1(1.81 \%)$ \\
IVh & $3(5.45 \%)$ & $5(9.09 \%)$ & $8(14.54 \%) *$ \\
Total & $9(16.36 \%)$ & $35(63.63 \%)$ & $44(80 \%)$ \\
\hline
\end{tabular}

* Strains harbored $p v$ included 3 isolates in each IVa and IVc subtypes and 1 isolate in each IVb and IVh subtype 
Table 5 Antibiotic resistance profile of S. aureus isolated from nasal carriers in Sanandaj city

\begin{tabular}{|c|c|c|c|c|c|c|}
\hline \multirow[t]{2}{*}{ Antibiotic } & \multicolumn{3}{|l|}{$\begin{array}{l}\text { S. aureus } \\
n=181\end{array}$} & \multicolumn{3}{|l|}{$\begin{array}{l}\text { MRSA } \\
n=55\end{array}$} \\
\hline & $\begin{array}{l}\mathrm{R} \\
\mathrm{n}(\%)\end{array}$ & $\begin{array}{l}\text { I } \\
\text { n (\%) }\end{array}$ & $\begin{array}{l}\text { S } \\
\text { n (\%) }\end{array}$ & $\begin{array}{l}\mathrm{R} \\
\mathrm{n}(\%)\end{array}$ & $\begin{array}{l}\text { I } \\
\text { n (\%) }\end{array}$ & $\begin{array}{l}\text { S } \\
\text { n (\%) }\end{array}$ \\
\hline Rifampin & $15(8.28 \%)$ & $8(4.41 \%)$ & $158(87.29 \%)$ & $3(5.45 \%)$ & $1(1.81 \%)$ & $51(92.72 \%)$ \\
\hline Tetracyclin & $33(18.23 \%)$ & $0(0 \%)$ & $148(81.76 \%)$ & $13(23.63 \%)$ & $0(0 \%)$ & $42(76.36 \%)$ \\
\hline Chloramphenicol & $39(21.54 \%)$ & $6(3.31 \%)$ & $136(75.13 \%)$ & $8(14.54 \%)$ & $1(1.81 \%)$ & $46(83.63 \%)$ \\
\hline Fusidic acid & $6(3.31 \%)$ & $0(0 \%)$ & $175(96.68 \%)$ & $1(1.81 \%)$ & $0(0 \%)$ & $54(98.18 \%)$ \\
\hline Trimethoprim-sulphamethoxazole & $17(9.39 \%)$ & $2(1.10 \%)$ & $162(89.50 \%)$ & $4(7.27 \%)$ & $0(0 \%)$ & $51(92.72 \%)$ \\
\hline Clindamycin & $142(78.45 \%)$ & $9(4.97 \%)$ & $30(16.57 \%)$ & $32(58.18 \%)$ & $4(7.27 \%)$ & 19 (34.54\%) \\
\hline Gentamicin & $4(2.20 \%)$ & $2(1.10 \%)$ & $175(96.68 \%)$ & $1(1.81 \%)$ & $0(0 \%)$ & $54(98.18 \%)$ \\
\hline Erythromycin & $92(50.82 \%)$ & $16(8.83 \%)$ & $73(40.33 \%)$ & $27(49.09 \%)$ & $2(3.63 \%)$ & $26(47.27 \%)$ \\
\hline Penicillin & $173(95.58 \%)$ & $0(0 \%)$ & $8(4.41 \%)$ & $55(100 \%)$ & $0(0 \%)$ & $0(0 \%)$ \\
\hline Vancomycin & $21(11.60 \%)$ & $9(4.97 \%)$ & 151 (83.42\%) & $6(10.90 \%)$ & $3(3.63 \%)$ & 46 (83.63\%) \\
\hline Mupirocin & $3(1.65 \%)$ & $1(0.55 \%)$ & 177 (97.79\%) & $0(0 \%)$ & $1(1.81 \%)$ & 54 (98.18\%) \\
\hline Ciprofloxacin & 87 (48.06\%) & $11(6.07 \%)$ & 83 (45.85\%) & 16 (29.09\%) & $3(3.63 \%)$ & $36(65.45 \%)$ \\
\hline
\end{tabular}

R: resistant; I: intermediate; S: sensitive; n: number

among teenagers [47]. The higher proportion of MRSA carriage state in male rather than female volunteers in this study complies with the results that presented elsewhere $[8,13,30,32]$. Indeed, this is coincide with the observations reported from Arak, central Iran [48] and the USA [49].

The frequent harboring of SCCmec type IV among the MRSA isolates underscored their community-acquired origin. Similarly, predominate SCCmec type among CAMRSA in other studies carried out in Iran $[8,41]$ and overseas $[11,12,14]$ was type IV. IVa subtype had the most frequency in Urmia, the northwest of Iran, with the association of none detectable IVb and IVc subtypes [8]. Lozano et al. revealed IVc subtype as the dominant subtype of SCCmec type IV [12]. This emphasizes even the subtle genetic variations of CA-MRSA isolated in different areas.

Because of the PVL-positive CA-MRSA menace to cause soft tissue and skin infections in menage and close-contact social groups, it is assumed as a serious public health threat. The frequency of $p v l$ gene among the CA-MRSA isolates in the present study was $14.54 \%$ ( 8 out of 55 isolates), which is higher than findings in the central [41] and the northwest of Iran [8]. While Fard-Mousavi et al. reported $20.8 \%$ prevalence for $p v l$ [48]. PVL-negative CA-MRSA clones were reported from Spain [12], Bolivia [11], and Botucatu, Brazil [14]. In contrast, approximately high prevalence of $p v l$-harboring CA-MRSA isolates were detected from Ukraine (58\%) [32]. Despite the prevailing distribution of $p v l$ in CA-MRSA clones in Western countries rather than Eastern countries [50], mountainous subtropical climate condition of Sanandaj city may influence the higher prevalence of $p v l$ in this city comparing to the mentioned European countries except Ukraine [51]. Meanwhile, due to the phage origin of $p v l$ genes and their transmissibility from methicillin-sensitive $S$. aureus (MSSA) into CA-MRSA, it is highly recommended to screen MSSA for the presence of this gene [52].

Approximately $100 \%$ sensitivity to mupirocin was observed herein. This is in line with the other reports from Iran $[8,41]$. Therefore, mupirocin can efficiently be used to mitigate MRSA nasal carriage [53]. Gentamicin is used as a synergic antibiotic in treatment of acute staphylococcal infections, like endocarditis. Fusidic acid is an appropriate alternative for the treatment of $S$. aureus infections in the cases of antibiotic resistance. In order to hinder the development of resistance against the above mentioned antimicrobials, diligent care in their use must be ensured. The same as the other internal data $[8,41]$, high rate of sensitivity against rifampin may be explained by the low prescription of this agent in medicine in Iran. Despite the reports from the northwest of Iran [8], high rate of resistance observed against clindamycin and erythromycin in this study may be a consequence of wide prescriptions of lincosamides and macrolides in treatment regime of gram positive bacterial infections in the region. Besides, there is obvious discrepancy regarding ciprofloxacin resistance rate in our study and others $[8,32,41]$ which may be depend on the easy access of individuals to it without physicians prescriptions. Hence, prudent prescription and limited access of individuals to antimicrobial agents in the region is highly recommended. 


\section{Conclusion}

In conclusion, the relatively high incidence of CAMRSA in asymptomatic individuals in the west of Iran is a worrisome matter. Hence, implementation of follow-up programs is crucial to restrict and/or interrupt transmission of the bacteria from infected carriers to in-contact persons. Presence of either drug-resistance or $p v l$-harboring isolates may emphasize more the application of further continuous surveillance in the region.

\section{Abbreviations}

BA: blood agar; CA: Columbia agar; CA-MRSA: community-acquired methicillin-resistant Staphylococcus aureus; Cl: confidence interval; HAMRSA: Hospital-acquired methicillin-resistant Staphylococcus aureus; MSA: mannitol salt agar; OR: odds ratio; PBP2a: penicillin-binding protein pvl: Panton-Valentine Leukocidin; SANC: Staphylococcus aureus nasal carriage; SCCmec: staphylococcal cassette chromosome mec; SNS: sterile normal saline

\section{Acknowledgments}

Not Applicable.

\section{Authors' contributions}

This study was conceived by EA, MK, SMM, JB, and MR. The laboratory work was performed by FK-M and AK. EA wrote this article. All the authors have read and approved the manuscript.

\section{Funding}

None.

\section{Availability of data and materials}

The datasets generated and/or analyzed during the current study are not publicly available since the data contains particular medical records and individual privacy could be compromised, but are available from the corresponding author on reasonable request.

\section{Ethics approval and consent to participate}

This study was approved by the Ethics Committee of the Sanandaj Medical University [no: 2340/01]. All subjects provided written informed consent. In the cases of participants less than 16 years old, consent was collected from the parents.

\section{Consent for publication}

Not applicable.

\section{Competing interests}

The authors declare that they have no competing interests.

\section{Author details}

${ }^{1}$ Department of Pathobiology, Faculty of Veterinary Medicine, Sanandaj Branch, Islamic Azad University, Sanandaj, Iran. ²Department of Microbiology, Faculty of Basic Sciences, Sanandaj Branch, Islamic Azad University, Sanandaj, Iran. ${ }^{3}$ Department of Microbiology, Faculty of Veterinary Medicine, Urmia University, Urmia, Iran. ${ }^{4}$ Young Researchers and Elite Club, Sanandaj Branch, Islamic Azad University, Sanandaj, Iran. ${ }^{5}$ Department of Basic Sciences, Faculty of Veterinary Medicine, Sanandaj Branch, Islamic Azad University, Sanandaj, Iran.

Received: 3 December 2018 Accepted: 16 October 2019 Published online: 28 October 2019

\section{References}

1. Pathak A, Marothi Y, lyer RV, Singh B, Sharma M, Eriksson B, et al. Nasal carriage and antimicrobial susceptibility of Staphylococcus aureus in healthy preschool children in Ujiain. India BMC Pediatr. 2010;10:100.

2. Frank DN, Feazel LM, Bessesen MT, Price CS, Janoff EN, Pace NR. The human nasal microbiota and Staphylococcus aureus carriage. PLoS One. 2010;5(5):e10598.
3. von Eiff C, Becker K, Machka K, Stammer H, Peters G. Nasal carriage as a source of Staphylococcus aureus bacteremia. Study Group N Engl J Med. 2001;344(1):11-6.

4. Chambers HF, Deleo FR. Waves of resistance: Staphylococcus aureus in the antibiotic era. Nat Rev Microbiol. 2009;7(9):629-41.

5. Magiorakos AP, Srinivasan A, Carey RB, Carmeli Y, Falagas ME, Giske CG, et al. Multidrug-resistant, extensively drug-resistant and pandrug-resistant bacteria: an international expert proposal for interim standard definitions for acquired resistance. Clin Microbiol Infect. 2012;18(3):268-81.

6. Katayama Y, Ito T, Hiramatsu K. A new class of genetic element, staphylococcus cassette chromosome mec, encodes methicillin resistance in Staphylococcus aureus. Antimicrob Agents Chemother. 2000:44(6):1549-55.

7. Hao H, Dai M, Wang Y, Huang L, Yuan Z. Key genetic elements and regulation systems in methicillin-resistant Staphylococcus aureus. Future Microbiol. 2012;7(11):1315-29.

8. Abroo S, Hosseini Jazani N, Sharifi Y. Methicillin-resistant Staphylococcus aureus nasal carriage between healthy students of medical and nonmedical universities. Am J Infect Control. 2017;45(7):709-12.

9. Jackson $\mathrm{KL}$, Mbagwu M, Pacheco JA, Baldridge AS, Viox DJ, Linneman JG, et al. Performance of an electronic health record-based phenotype algorithm to identify community associated methicillin-resistant Staphylococcus aureus cases and controls for genetic association studies. BMC Infect Dis. 2016;16(1):684

10. Boyle-Vavra S, Daum RS. Community-acquired methicillin-resistant Staphylococcus aureus: the role of Panton-valentine leukocidin. Lab Investig. 2007;87(1):3-9.

11. Bartoloni A, Pallecchi L, Fernandez C, Mantella A, Riccobono E, Magnelli D, et al. Low prevalence of methicillin-resistant Staphylococcus aureus nasal carriage in urban and rural community settings in Bolivia and Peru. Int J Infect Dis. 2013;17(5):e339-42.

12. Lozano C, Gomez-Sanz E, Benito D, Aspiroz C, Zarazaga M, Torres C. Staphylococcus aureus nasal carriage, virulence traits, antibiotic resistance mechanisms, and genetic lineages in healthy humans in Spain, with detection of CC398 and CC97 strains. Int J Med Microbiol. 2011;301(6):500-5.

13. Mehraj J, Akmatov MK, Strompl J, Gatzemeier A, Layer F, Werner G, et al. Methicillin-sensitive and methicillin-resistant Staphylococcus aureus nasal carriage in a random sample of non-hospitalized adult population in northern Germany. PLoS One. 2014;9(9):e107937.

14. Pires FV, da Cunha ML, Abraao LM, Martins PY, Camargo CH, Fortaleza CM. Nasal carriage of Staphylococcus aureus in Botucatu, Brazil: a populationbased survey. PLoS One. 2014;9(3):e92537.

15. Mobasherizadeh S, Shojaei H, Havaei SA, Mostafavizadeh K, Davoodabadi F, Khorvash F, et al. Nasal carriage screening of community-associated methicillin resistant Staphylococcus aureus in healthy children of a developing country. Adv Biomed Res. 2016;5:144

16. Nikfar R, Shamsizadeh A, Ziaei Kajbaf T, Kamali Panah M, Khaghani S, Moghddam M. Frequency of methicillin-resistant Staphylococcus aureus nasal carriage in healthy children. Iran J Microbiol. 2015;7(2):67-71.

17. Rahimi F, Katouli M, Pourshafie MR. Characteristics of hospital- and community-acquired meticillin-resistant Staphylococcus aureus in Tehran. Iran J Med Microbiol. 2014;63:796-804.

18. Shokouhi S, Darazam IA, Zamanian MH. Community-acquired methicillinresistant Staphylococcus aureus carriage rate and antimicrobial susceptibility in a tertiary center. Iran J Res Med Sci. 2017;22:71.

19. Brakstad OG, Aasbakk K, Maeland JA. Detection of Staphylococcus aureus by polymerase chain reaction amplification of the nuc gene. J Clin Microbiol. 1992;30(7):1654-60.

20. Wayne P. Clinical and laboratory standards institute. Performance standards for antimicrobial susceptibility testing 2011.

21. Geha DJ, Uhl JR, Gustaferro CA, Persing DH. Multiplex PCR for identification of methicillin-resistant staphylococci in the clinical laboratory. J Clin Microbiol. 1994;32(7):1768-72.

22. Ghaznavi-Rad E, Nor Shamsudin M, Sekawi Z, van Belkum A, Neela V. A simplified multiplex PCR assay for fast and easy discrimination of globally distributed staphylococcal cassette chromosome mec types in meticillinresistant Staphylococcus aureus. J Med Microbiol. 2010;59:1135-9.

23. Lina G, Piemont Y, Godail-Gamot F, Bes M, Peter MO, Gauduchon V, et al. Involvment of Panton-valentine leukocidin-producing Staphylococcus aureus in primary skin infections and pneumonia. Clin Infect Dis. 1999;29(5):1128-32.

24. Liu SH, Chen KF, Chen CJ, Lin YH, Huang YC. Intermittent nasal carriage with Staphylococcusaureus within a menstrual cycle: results from a prospective cohort of healthy carriers. Medicine. 2016;95(26):e4040. 
25. Zanger P, Nurjadi D, Gaile M, Gabrysch S, Kremsner PG. Hormonal contraceptive use and persistent Staphylococcus aureus nasal carraige. Clin Infect Dis. 2012;55(12):1625-32.

26. Pennell LM, Galligan CL, Fish EN. Sex affects immunity. J Autoimmun. 2012; 38(2-3):282-91.

27. Straub $\mathrm{RH}$. The complex role of estrogens in inflammation. Endocr Rev. 2007;28(5):521-74.

28. Siivonen L. Sex steroid receptors in papilloma, normal mucosa and polyps of the nose. ORL J Otorhinolaryngol Relat Spec. 1994;56(3):154-6.

29. Lamikanra A, Olusanya Ol. A long-term study of the nasal carriage of Staphylococcus aureus in healthy Nigerian students. Trans R Soc Trop Med Hyg. 1988;82(3):500-2.

30. Skramm I, Moen AE, Bukholm G. Nasal carriage of Staphylococcus aureus: frequency and molecular diversity in a randomly sampled Norwegian community population. APMIS. 2011;119(8):522-8.

31. Fomda BA, Thokar MA, Khan A, Bhat JA, Zahoor D, Bashir G, et al. Nasal carriage of methicillin-resistant Staphylococcus aureus among healthy population of Kashmir. India Indian J Med Microbiol. 2014;32(1):39-43.

32. Netsvyetayeva I, Fraczek M, Piskorska K, Golas M, Sikora M, Mlynarczyk A, et al. Staphylococcus aureus nasal carriage in Ukraine: antibacterial resistance and virulence factor encoding genes. BMC Infect Dis. 2014;14:128.

33. Durupt F, Mayor L, Bes M, Reverdy ME, Vandenesch F, Thomas L, et al. Prevalence of Staphylococcus aureus toxins and nasal carriage in furuncles and impetigo. Br J Dermatol. 2007;157(6):1161-7.

34. Fritz SA, Epplin EK, Garbutt J, Storch GA. Skin infection in children colonized with community-associated methicillin-resistant Staphylococcus aureus. J Inf Secur. 2009;59(6):394-401.

35. Ertam I, Biyikli SE, Yazkan FA, Aytimur D, Alper S. The frequency of nasal carriage in chronic urticaria patients. J Eur Acad Dermatol Venereol. 2007; 21(6):777-80.

36. Talpur R, Bassett R, Duvic M. Prevalence and treatment of Staphylococcus aureus colonization in patients with mycosis fungoides and Sézary syndrome. Br J Dermatol. 2008;159(1):105-12.

37. Petry V, Lipnharski C, Bessa GR, Silveira VB, Weber MB, Bonamigo RR, et al. Prevalence of community-acquired methicillin-resistant Staphylococcus aureus and antibiotic resistance in patients with atopic dermatitis in Porto Alegre. Brazil Int J Dermatol. 2014;53(6):731-5.

38. Rahimian J, Khan R, LaScalea KA. Does nasal colonization or mupirocin treatment affect recurrence of methicillin-resistant Staphylococcus aureus skin and skin structure infections? Infect Control Hosp Epidemiol. 2007; 28(12):1415-6.

39. Askarian M, Zeinalzadeh A, Japoni A, Alborzi A, Memish ZA. Prevalence of nasal carriage of methicillin-resistant Staphylococcus aureus and its antibiotic susceptibility pattern in healthcare workers at Namazi hospital, shiraz. Iran Int J Infect Dis. 2009;13(5):e241-7.

40. Mohajeri P, Izadi B, Rezaei M, Farahani A. Frequency distribution of hospitalacquired MRSA nasal carriage among hospitalized patients in west of Iran. Jundishapur J Microbiol. 2013;6(6):e9076.

41. Japoni-Nejad A, Rezazadeh M, Kazemian H, Fardmousavi N, van Belkum A, Ghaznavi-Rad E. Molecular characterization of the first community-acquired methicillin-resistant Staphylococcus aureus strains from Central Iran. Int J Infect Dis. 2013;17(11):e949-54.

42. Goud R, Gupta S, Neogi U, Agarwal D, Naidu K. Community prevalence of methicillin and vancomycin resistant Staphylococcus aureus in and around Bangalore, southern India. Rev Soc Bras Med Trop. 2011:44(3):309-12.

43. Scerri J, Monecke S, Borg MA. Prevalence and characteristics of community carriage of methicillin-resistant Staphylococcus aureus in Malta. J Epidemio Glob Health. 2013;3(3):165-73.

44. Onanuga A, Temedie TC. Nasal carriage of multi-drug resistant Staphylococcus aureus in healthy inhabitants of Amassoma in Niger delta region of Nigeria. Afr Health Sci. 2011;11(2):176-81.

45. Bratu S, Landman D, Gupta J, Trehan M, Panwar M, Quale J. A populationbased study examining the emergence of community-associated methicillin-resistant Staphylococcus aureus USA300 in New York City. Ann Clin Microbiol Antimicrob. 2006;5:29.

46. Rihn JA, Paosfay-Barbe K, Harner CD, Macurak A, Farley A, Greenawalt K, et al. Community-acquired methicillin-resistant Staphylococcus aureus outbreak in a local high school football team unsuccessful interventions. Pediatr Infect Dis J. 2005;24(9):841-3.
47. Schaumburg F, Kock R, Friedrich AW, Soulanoudjingar S, Ngoa UA, von Eiff

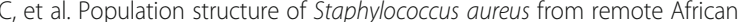
Babongo pygmies. PLoS Negl Trop Dis. 2011;5(5):e1150.

48. Fard-Mousavi N, Mosayebi G, Amouzandeh-Nobaveh A, Japouni-Nejad A, Ghaznavi-Rad E. The dynamic of Staphylococcus aureus nasal carriage in Central Iran. Jundishapur J Microbiol. 2015;8(7):e20760.

49. Mainous AG 3rd, Hueston WJ, Everett CJ, Diaz VA. Nasal carriage of Staphylococcus aureus and methicillin-resistant $S$ aureus in the United States, 2001-2002. Ann Fam Med. 2006:4(2):132-7.

50. David MZ, Glikman D, Crawford SA, Peng J, King KJ, Hostetler MA, et al. What is community-associated methicillin-resistant Staphylococcus aureus? J Infect Dis. 2008;197(9):1235-43.

51. Zanger P, Nurjadi D, Schleucher R, Scherbaum H, Wolz C, Kremsner PG, et al. Import and spread of Panton-valentine Leukocidin-positive Staphylococcus aureus through nasal carriage and skin infections in travelers returning from the tropics and subtropics. Clin Infect Dis. 2012;54(4):483-92.

52. Deurenberg RH, Beisser PS, Visschert MJ, Driessen C, Stobberingh EE. Molecular typing of methicillin-susceptible Staphylococcus aureus isolates collected in the Yogyakarta area in Indonesia, 2006. Clin Microbiol Infect. 2010;16(1):92-4.

53. Henkel T, Finlay J. Emergence of resistance during mupirocin in treatment: is it a problem in clinical practice? J Chemother. 1999:11(5):331-7.

\section{Publisher's Note}

Springer Nature remains neutral with regard to jurisdictional claims in published maps and institutional affiliations.
Ready to submit your research? Choose BMC and benefit from:

- fast, convenient online submission

- thorough peer review by experienced researchers in your field

- rapid publication on acceptance

- support for research data, including large and complex data types

- gold Open Access which fosters wider collaboration and increased citations

- maximum visibility for your research: over $100 \mathrm{M}$ website views per year

At $\mathrm{BMC}$, research is always in progress.

Learn more biomedcentral.com/submissions 